This item was submitted to Loughborough's Research Repository by the author.

Items in Figshare are protected by copyright, with all rights reserved, unless otherwise indicated.

\title{
Strategic cities within global urban networks
}

PLEASE CITE THE PUBLISHED VERSION

https://www.routledge.com/The-Routledge-Companion-to-the-Geography-of-International-Business/CookJohns-McDonald-Beaverstock-Pandit/p/book/9781138953345

PUBLISHER

(c) Routledge

VERSION

AM (Accepted Manuscript)

PUBLISHER STATEMENT

This is an Accepted Manuscript of a book chapter published by Routledge in The Routledge Companion to the Geography of International Business on 29 March 2018, available online: http://www.routledge.com/9781138953345.

\section{LICENCE}

CC BY-NC-ND 4.0

\section{REPOSITORY RECORD}

Derudder, Ben, Peter J. Taylor, James R. Faulconbridge, and Pengfei Ni. 2019. "Strategic Cities Within Global Urban Networks". figshare. https://hdl.handle.net/2134/33041. 


\section{Strategic cities within global urban networks ${ }^{1}$}

Ben Derudder, Peter J. Taylor, James Faulconbridge, Michael Hoyler and Pengfei Ni

\section{Introduction}

The prime purpose of this chapter is to investigate cities as strategic places in contemporary globalization using the methodology developed as world city network analysis (Taylor, 2001; Taylor and Derudder, 2016). To this end, we draw on the work of Sassen (1991, 3-4), who in her classic book The Global City identified processes of globalization that had 'created a new strategic role for major cities' resulting in a 'new type of city'. Our approach deals with many more cities than Sassen considers: here we ask the question, which of these numerous cities can be reasonably identified as strategic places? We deploy world city network analysis findings to answer this question quantitatively, so that amongst the cities thus identified we can measure degrees of 'strategic-ness'. From this we explore different ways in which cities are being strategic drawing on the literature dealing with selected individual cities.

We treat the concept of strategic places from two directions. From the perspective of cities there are key firms that operate as strategic networks,

1 This chapters presents an empirical and interpretational update of a paper published in Economic Geography as Taylor, P.J., Derudder, B., Faulconbridge, J., Hoyler, M. \& Ni, P. (2014) 'Advanced producer service firms as strategic networks, global cities as strategic places', Economic Geography, 90, 267-291. Data used in this chapter are for 2016 instead of 2010, and contents have been revised and updated accordingly. Operational details and dicussion of results have been shortened and amended respectively, and in this chapter we have included a more thorough dicussion of related research, some of which has been published since the writing-up of the initial paper. 
which cities need to be part of; but equally, from the perspective of firms there are key cities that are strategic places, where firms have to be.

We build this analysis and interpretation on the foundations provided by literatures documenting the internationalization of advanced producer service firms such as accountancy, advertising, architecture, finance and law (Daniels, 1993; Bagchi-Sen and Sen, 1997; Jones, 2002; Bryson et al., 2004; Faulconbridge et al., 2008). This literature details the way firms' policies target particular city spaces (and thus render them strategic) as part of efforts to construct coordination capabilities that support both markets' exploitation/development and innovation priorities. We thus attempt to provide a distinct empirical contribution to the discussion based on the foundations of the literature on the internationalization policies of advanced producer service firms: a stronglyevidenced, theoretically-sound set of results that do add something new to understanding cities in globalization.

Our argument proceeds in seven parts: (i) we present the basic model that we use which specifies contemporary inter-city relations as an interlocking network; (ii) we outline the connections between the location policies of internationalizing advanced producer service firms and the production of strategic city places; (iii) we describe the data required to operationalize the model by creating a service values matrix showing how firms use cities, and initial forms of analyses from these data are described for both firms and cities; (iv) specific findings for 2016 data are presented describing city-dyad contrasts and globalization strategies of firms; (v) strategic networks are derived from the 
globalization strategies and these are employed to identify strategic places; (vi) the strategic-ness of cities is derived by relating strategic network positions to cities' encompassing global network positions; and (vii) we interpret our findings in relation to what the literature says about a number of specific cities we have found to be strategic places.

\section{Advanced producer service internationalization through strategic cities}

Since the seminal work on the role of advanced producer services (APS) in the global economy (Enderwick, 1989; Beyers, 1992; Daniels, 1993, 1995), questions about the strategic role of cities have been at the forefront of concerns. Originally centred around questions about why APS cluster in cities, and spurning extensive analysis of the way city economies function using agglomeration and localization logics and their explanations of markets and innovation processes respectively (Pryke, 1994; Grabher, 2001), this literature has developed since the late 2000s as questions about the way cities play varying roles in firms' strategies have come to the fore (Warf, 2001; Jones, 2002; Beaverstock, 2007; Faulconbridge et al., 2007, 2008, 2011; McNeill, 2008). In this regard, Bagchi-Sen and Sen (1997) were ahead of their time when they deployed Dunning and Norman's (1983) eclectic paradigm to analyse the location advantages for APS of different cities. In this work, the 'size and character of the market; regulation of markets ... and the location of human (skilled labor) and physical assets' were identified as core factors influencing where internationalizing APS chose to establish foreign outposts (Bagchi-Sen and Sen, 1997, 1158). However, even at this early stage of research, it was noted that 'sector differentiation in terms of 
internationalization strategies' (p. 1171) was crucial, accounting and advertising being compared and contrasted by Bagchi-Sen and Sen (1997).

Further inspired by calls to open the black box used to represent firms and their strategies in studies of corporations driving economic globalization (Taylor and Asheim, 2001; Yeung, 2005), the most recent research on APS internationalization, therefore, seeks to identify (i) groups of firms that share common strategic objectives, and (ii) the differing role of cities in fulfilling these objectives. In relation to issue (i), it is possible to distinguish between what might be called the ubiquitous presence versus the strategic presence approach. The former, most commonly adopted by the Big Four accountancy firms (Beaverstock, 1996), major financial institutions (Wójcik, 2013) and hybrid producer-consumer services such as temporary staffing agencies (Coe et al., 2007), involves maintaining a presence in as many cities as possible to allow revenue maximization through the servicing of local clients' needs. The latter, associated more with advertising (Faulconbridge et al., 2011), architecture (McNeill, 2008) and law firms (Faulconbridge, 2008), is driven by a desire to locate offices in the most strategically important places, strategic importance being defined in terms of both the global influence and connectedness of markets and the extent to which work in these places is cutting edge in terms of innovation and thus global profile.

Connected to questions about internationalization strategy and the more or less strategic role of different places, are also questions about the organizational form of APS. For instance, Faulconbridge et al. (2008) synthesize a range of 
research on APS and apply it to the case of executive search to reveal that depending on the strategic importance of a city, internationalization may involve: owned offices (traditional foreign direct investment); the establishment of networks (collaboration with local independent APS rather than direct investment); or a hybrid of the two former approaches (investment in already existing local APS that retain some autonomy but become tightly integrated into global corporate networks). Whilst there is some variability, owned strategies tend to be associated with the most strategically important sites, whilst networks are used to provide presence when needed in markets that are uncertain in terms of regulatory barriers, stability or strategic importance. Hybrids allowed mid-ranking city nodes that are integrated into global economic flows, but in less strategic ways, to be effectively served. The example of the executive search firm Korn/Ferry given by Faulconbridge et al. (2008) is illustrative of such connections between organizational form and the strategicness of a city. Owned offices dominate the firm's internationalization strategy, which involves presence in a total of over 70 cities. However, the owned approach is restricted to the most strategic locations, such as London, New York, Frankfurt, etc. Hybrid forms are used in locations that have less strategic importance, for instance in Mexico City and Monterey, whilst networks allow a flag to be planted in locations of potential future importance (e.g., Johannesburg) or where a token presence is required but markets are limited (e.g., Auckland).

The APS literature reveals, then, two important insights relevant to the analysis and interpretation of the way cities do or do not become strategic places in the 
world city network created by APS firms. First, it shows that not all APS have the same significance when presence or absence is being used as a proxy of strategicness. The ubiquitous presence strategy means that sectors such as accounting and finance potentially maintain a presence in both more and less strategic cities. Hence these sectors may not be good measures of strategicness. Meanwhile, other sectors that adopt a strategic presence approach may be better suited to analyses seeking proxies for city strategicness. Second, the APS literature also reveals that whilst a firm may have tens or hundreds of offices, not all of these offices share an equal level of strategic importance. Variations in strategicness may be reflected in the organizational form used to manage presence and also in other characteristics such as size and staffing. With these insights in mind, the remainder of the paper considers how such understandings of variations in the strategic role of cities in APS internationalization might be both captured in world city network analysis methodologies and used to understand the urban spatial architecture of current day global capitalism.

\section{Basic model: interlocking network specification}

To deploy the insights gained from the APS literature, it is important to consider their implications for the assumptions in the interlocking network model used in world city network analysis (for an overview, see Taylor and Derudder, 2016). The choice of specifying advanced producer service firms as the economic agents making the world city network derives directly from Sassen's (1991) identification of this economic sector as key creator of her global cities. This occurs in two ways. First, global cities through their 'control and command 
functions' house corporate headquarters and agencies of government that provide the main market for advanced producer services. Second, it is these cities that are the production centres for advanced producer services, the places where product and process innovations keep growing this cutting edge economic sector. This consumption/production dual character of global cities will have a central role in interpreting the strategic places we identify below. However, we depart from Sassen's use of advanced producer services to identify a small subset of cities as 'global' and instead recognize that advanced producer services are much more widespread than her discussion implies. We define a world city network based upon the activities of advanced producer service firms that encompasses several hundred cities across the world. Thus we specify the world city network in terms of the worldwide office networks of leading advanced producer service firms.

The world city network is formally specified in Taylor (2001); here we provide the basic outline. The network is represented by a city-by-firm matrix $\mathbf{V}_{\mathrm{ij}}$, where $v_{i, j}$ is the 'service value' of city i to firm $j$. This service value is a standardized measure of the importance of a city to a firm's office network, which depends on the size and functions of a firm's office(s) in a city.

The city-dyad connectivity between two cities a and $\mathrm{i}\left(\mathrm{CDC}_{\mathrm{a}-\mathrm{i}}\right)$ is defined as:

$$
\mathrm{CDC}_{\mathrm{a}-\mathrm{i}}=\sum \mathrm{v}_{\mathrm{a}, \mathrm{j}} \cdot \mathrm{v}_{\mathrm{i}, \mathrm{j}} \quad(\text { where } \mathrm{a} \neq \mathrm{i})
$$

This provides a measure of the potential work flows, transfers of information and knowledge, between pairs of cities. The assumption behind conceiving the product of service values as a surrogate for actual flows between cities a and i for 
firm $\mathrm{j}$ is that the more important the office, the more links there will be with other offices in a firm's network. In other words, we are using a simple interaction relation as our measure of connectivity: two cities housing large offices will generate more inter-city work flows between them than two cities each with small offices.

Typically in world city network analysis these inter-city connectivities are aggregated for each city and the totals are interpreted as the global network connectivity of a city $\left(\mathrm{GNC}_{\mathrm{a}}\right)$, indicating a city's overall importance within the network:

$$
\mathrm{GNC}_{\mathrm{a}}=\sum \mathrm{CDC}_{\mathrm{a}-\mathrm{i}} \quad(\text { where } \mathrm{a} \neq \mathrm{i})
$$

This has been the main measure derived from the model and can be interpreted as how well a city is integrated into the world city network, and hence its 'global status'.

\section{Basic data: filling the service values matrix}

To operationalize this model requires assessment of firms' office networks to empirically construct a city-by-firm matrix $\mathbf{V}_{\mathrm{ij}}$ of service values. The data required for this exercise are readily available on firms' websites where they promote their 'global' status as a means of both impressing clients in a competitive services market and recruiting graduates in a competitive jobs market. However this source, plus supplementary information as available, produces different levels and types of information for every firm. Thus for each firm the data have to be converted by using a simple coding system to enable 
cross-firm comparison for analysis. We use a coding from 0 to 5 , whereby the service values $v_{i, j}$ : 0 indicates a city where firm $\mathrm{j}$ has no presence and 5 is firm j's headquarter city. Codes 1 to 4 are then allocated as follows: a typical office of firm j scores a city 2 , there must be something deficient to lower the score to 1 , and something extra for it to rise above 2. For the latter, an especially large office scores 3, an office with extra-city jurisdictions (e.g. regional HQ) scores 4. Each firm is assessed individually to decide on boundary decisions away from 2 . With $n$ firms and $m$ cities, such data collection creates an $n$ firms $x m$ cities array of service values, the basic matrix for interlocking network analysis. Each column of the matrix shows a firm's location strategy as a string of integers from 0 to 5 across $m$ cities; each row shows a city's service mix as a string from 0 to 5 across $n$ firms.

In 2016 we assessed the office networks of 175 firms across 707 cities. The former consisted of 75 financial services firms and 25 each of accountancy, advertising, law and management consultancy firms. Firms were chosen using trade information ranking firms by size based upon the latest information available (e.g. on turnover). Cities were chosen on the basis of previous experience in this work (315 cities used in earlier data collections) plus all other cities with more than 2 million population, all other capital cities of countries with over one million population, and all other cities housing the headquarters of one of our 175 firms. These are arbitrary rules of inclusion but the aim was to include more cities than necessary so as not to exclude any potentially relevant cities in what is a very dynamic process of world city network formation. The 
end result is a 175 firms x 707 cities matrix for 2016 providing 123,725 service values for analysis.

\section{Extensive and intensive globalization}

Our identification of strategic cities is premised on an initial exploration of the location strategies of the advanced producer service firms. Their office networks constitute 175 specific location strategies, depending on idiosyncrasies, market analysis, historical trajectories, regulatory boundaries, etc. The outcome of these processes at any one point in time constitutes firms' specific location strategies. This particular geography is represented by a firm's column of integers in the service values matrix; for 2016 we have 175 such strategies. Although every strategy is different across our firms there are some clear similarities amongst them that can be teased out using a principal components analysis. This technique is a 'data reduction' method that converts $\mathrm{x}$ variables into $\mathrm{y}$ components where $\mathrm{y}$ is appreciably smaller than $\mathrm{x}$. This is achieved by using the correlations between variables to combine them into groups of like variables, the 'principal components' of the data. The importance of each component is derived from its correlations (called 'loadings') with the original variables. In the analysis reported here the 175 individual firm location strategies (variables) are reduced to just two components that are interpreted as the most common dimensions of location strategies: between them, these two components account for almost one-third of the common variance found in the service values matrix. We concentrate on these two common location strategies here. 
The characteristics of principal components can be discerned from their component scores on the objects of the analysis, in this case the cities. The scores for the two main components identified above, illustrating the two leading common location strategies from the 2016 service values matrix, are given in Table 1 for all cities scoring $>0.50$. These strategies are labelled intensive and extensive globalizations for reasons that will become apparent as we describe them. In each case we identify a 'home-region' on which the strategy is centred most of the headquarters of the firms that constitute each component are to be found here (see Taylor et al., 2013) - and a 'global outreach' that identifies how the rest of the world is serviced through the location strategy. In both cases we find the home-region encompasses US cities plus London. However, although overlapping, the constitution of these two regions is quite distinctive: in the first list in Table 2 there are 9 US cities plus London, in the second just New York and London. With global outreach we find the obverse: just three cities in the first list but with 40 featuring in the second list. The reason for their specific labels is as follows. The intensive globalization strategy focuses on the prime locus through which economic globalization was initially constructed with the rest of the world serviced through just key cities in each of the two other major 'globalization arenas' - Brussels in Western Europe and Hong Kong and Beijing in Pacific Asia. In contrast the extensive globalization strategy emanates from just the two cities continuously found at the apex of the world city network combined with a very comprehensive servicing across the rest of the world. 


\section{Identifying strategic networks and strategic places}

In our model it is the firms that are the agents of globalization, the transnational network makers, and therefore to comprehend strategy we start by identifying strategic firms, and then use them to find the strategic places that are our initial concern in this chapter.

Although the two components are orthogonal (i.e. not related, their correlation equals zero), there will be specific firms that use elements of both common strategies as reflected in their loadings on the two components. These are the firms we will identify as 'global strategic firms'. Specifically, we use firms' component loadings on (i.e. levels of correlations with) the intensive and extensive globalization strategies to define a 'global strategic measure' for all 175 firms in our data. We compute the product of the loadings on the two components for each firm to create this measure. Global strategic firms are then identified as the 25 firms with the largest component loading above. The basic reasoning behind this procedure is to find firms with relatively high positive loadings on both components. Thus firms with a negative loading on one of the components are immediately eliminated. Firms scoring high on one component but not the other are similarly discarded. The results of this exercise are shown in Table 2 where 25 global strategic firms are listed.

We can see from Table 2 that all five service sectors in our data are represented, albeit very unevenly so. Management consultancy, accountancy, and advertising only have one or two firms present. Financial services are somewhat more 
represented, but note that firms present here are above all US-headquartered investment banks and there were three times as much financial services firms compared to the other sectors. Thus the key sector represented is law with 12 firms, all of which are headquartered in either London or a leading US city.

We are now in a position to identify which cities are strategic places within the world city network: we define these as cities that house offices of 10 or more strategic firms. This produces a list of 49 cities shown in Table $3^{2}$. The cities are ranked by their strategic network connectivity derived from computing the network connectivity defined by equations (1) and (2) but only including the 25 strategic firms in the calculations. All 25 strategic firms are found in London and New York, the latter is ranked higher because its offices tend to be more important than London's (e.g. more headquarters): this is shown by the higher connectivity New York obtains from its strategic firms' offices.

\section{Relating strategic network connectivity to global network connectivity}

We have regressed strategic network connectivity against global network connectivity and recorded the residuals. These are standardized (zero mean and a standard deviation of one) so that positive numbers indicate relative strategic over-connected-ness and negative numbers relative strategic under-connected-

\footnotetext{
2 It should be noted that although this methodology includes arbitrary threshold decisions for defining strategic firms and strategic places, these were not the only ones tested in the research. The key point is that the different choices had very little effect on subsequent analysis. In other words, the results we present below are quite robust with minor differences having no relevance to the broader conclusions drawn.
} 
ness. In Table 4 cities are ranked by size of their residuals to show the importance of their strategic connectivity relative to overall connectivity.

The follow findings from this analysis are highlighted:

- Although both New York and London are strategically over-connected there is a clear difference between New York and London: the former is much more over-connected city relative to its global connectivity. In most of our analyses both cities are hard to separate in their connectivity profile, with London most commonly being somewhat more connected, but on this particular measure New York appears to be more central.

- Other leading US cities are also ranked high on this relative measure: Washington, DC, Los Angeles, Chicago and San Francisco are also strategically over-connected, as are secondary cities such as Miami and Houston. Very few North American cities have a negative residual, with Toronto as leading Canadian city having a very large negative residual.

- Although there is much continuity with the initial study drawing on 2010 data (Taylor et al., 2014), the presence of Washington, DC represents a major change. The really interesting continuity is the presence of Palo Alto. Ranked a lowly 283rd in global network connectivity, which is even lower than in 2010, it has the second most strategic connectivity, which obviously reflects its special positionality in Silicon Valley.

- Although Mainland Chinese cities are increasingly important in terms of global network connectivity (especially Shanghai and Beijing) this is not being reflected in strategicness. 
- Cities from other erstwhile 'third world' countries are generally underconnected: Buenos Aires, Jakarta, Kuala Lumpur, Mexico City, Ho Chi Minh City, Bangkok, and Mumbai all have large negative residuals have large negative residuals.

- Dubai, Abu Dhabi and Doha have posted major connectivity gains over the past years (see Derudder and Taylor, 2016), but this does not translate into major strategic positions: residuals are positive, but relatively small.

This strategic network geography that we have uncovered within the world city network forms the basis of our specific interpretations of strategic places and their differences below.

\section{Interpretation of positionalities}

The quantitative findings shown in Table 4 require interpretation based upon both theoretical extensions of the model employed and empirical knowledge of the cities as advanced producer service centres. In practice these two needs cannot be separated (and this is particularly the case when we try and comprehend our results on New York and London). However, in terms of the empirics, clearly we cannot deal with all 48 cities and therefore we proceed as follows. We begin with consideration of London and New York, surely the world's most studied cities, and focus on writings that have discussed their differences. We then deploy what we have learned from this prime city-dyad comparison to other specific cases. These are chosen from a mixture of intrinsic 
interest and availability of relevant literature to meet our needs. Thus we deal with Mainland Chinese cities, Palo Alto (the highly strategic but weakly connected city), Mexico City (an emerging market city).

\section{London and New York}

London and New York define the only city-dyad that actually has a name: NYLON. It is part of a tradition that sees these cities at the forefront of fashion and which has been enhanced by economic globalization whereby leading world movers and shakers are said to work through three offices, one in each city and another in transit over the Atlantic. Smith $(2012,421)$ describes how these two cities have come to be viewed as a single city: 'a transatlantic metropolis that is the heart-beat of the global economy'. The key point that Smith makes is that the cities operate in conjunction for the benefit of a small rich minority. But the conflation of the two cities hides the differences that we are seeking. Their complementarities are based upon dissimilarity and this has been the subject of a careful comparison as global financial centres by Sassen (1999) and Wójcik (2013).

According to Sassen $(1999,81)$ New York and London constitute 'a cooperative division of labor' that operates as follows:

(i) 'London is the preeminent city for global finance today, in good part due to numerous international firms that have located key operations and resources in the City [so that] London's unique denationalized platform for global operations gives it its competitive advantage' (pp. 83-4); 
(ii) But 'what London lacks is Wall Street's brilliant financial engineering' and therefore 'New York dominates in another way by offering market innovations and new financial products. Wall street - still the Silicon Valley of finance - has made U.S. investment firms leaders in the global market' (pp. 83-4).

More than a decade later it seems that this differentiation is still very much in place; Wójcik (2013, 6-7), partly drawing on Strange (1997) and Michie (2006), describes it this way:

'While New York commands access to the largest and most liquid domestic financial market in the world, London's physical, political and historical geography implies access to a different time zone, European markets, and global connections ... Taking advantage of its sheer liquid domestic market, and the deepest pool of financial engineering talent, New York leads financial innovation... Hedge funds come from the USA, and so do venture capital and private equity. Most new products and methods of trading in the global securities markets emanated from New York.... London, in turn, has specialized as a centre, where financial firms (with US banks in the lead) adapt financial innovation from the USA to foreign and international markets.'

The message is clear: London is particularly good for global financial business, New York is particularly good for global financial innovations.

London thus appears to be better integrating business while New York is more specialized in building new functions, the latter interpreted as being more strategic. Further, there is a sense in which London is 'used' with New York firms 
as key 'users', indicating a hierarchical element in the cities' complementarities that Sassen $(1999,81)$ recognized. And returning to her essential 'global city' process (Sassen, 1991) where the city is both a market for and a producer of APS, we can view the relationship between these two functions as variable across cities: high levels of new production relative to market (exchange) is a distinctive strategic place process, more focus on market service than production is a general network process. Indeed, we can see just such a distinction in the strategies of internationalizing US law firms. In the initial years at least, these firms primarily practiced US (and New York specifically) law in London as part of a strategy designed to exploit the demand for advice about the structuring of financial transactions using New York law (Warf, 2001; Cullen-Mandikos and MacPherson, 2002). Such an interpretation provides both an explanation for our results showing New York exhibiting more 'strategic-ness' than London, and also suggests a general means of comparing cities in the world city network in terms of their relative strategic-ness.

\section{Beijing, Hong Kong and Shanghai}

To illustrate the latter we can turn briefly to the China cities in our analysis using Lai's (2012) study of the mutualities between Beijing, Hong Kong and Shanghai as financial centres. She describes a 'dual headquarter strategy' for BeijingShanghai relations and 'parallel markets' for Hong Kong-Shanghai relations. She equates Hong Kong's role with that of New York (p. 1275), and this does indeed emerge in our findings with Hong Kong being the most strategic connected outside of the US. 
The roles of the three China cities are quite distinctive. Beijing is the political centre, 'responsible for policy-making and macro planning' (Lai, 2012, 1283), in other words the locus of command and control. Shanghai, on the other hand, 'is tasked with testing new products, developing new markets and financial innovation' (p. 1283). The result is that Shanghai has 'the highest concentration of foreign banks' and hosts 'new financial markets in futures, derivatives and foreign exchange' (p. 1283). In contrast Hong Kong has grown as a strategic conduit 'connecting global capital and China' (p. 1275) and continues in the role of China's 'offshore financial centre.' (p. 1275).

It takes very little imagination to equate this structural logic to similar relations between Washington as political centre, New York as innovative centre, and London as offshore centre. In the latter case both London and Hong Kong have exploited a political autonomy by being outside the direct sovereign/administrative control of the USA and China respectively. In other words these are necessary global platforms where you can do things that are not possible in the cities of the USA and mainland China.

\section{Palo Alto}

As the main city in Silicon Valley, Palo Alto is a very special strategic place, as reflected in our analysis through its unusual combination of very low general integration into the world city network with very high strategic-ness. How does the production of high tech innovations that Silicon Valley is famous for transfer into APS innovation as our results imply? This special place has distinctive servicing needs that have led to specialization in deal making, advising new firm 
start-ups and university spin-offs, arranging access to venture capital, taking successful firms public, plus mergers and acquisitions activity (Lashinsky, 2002; Reiffenstein, 2009). The main service sector providing these services is law and law firms, working as 'patent attorneys' in particular, illustrate servicing the business of innovation (Reiffenstein, 2009).

According to Reiffenstein $(2009,572)$ law firms 'by mediating between the private interests of firms and the public concerns of the patent office, perform a critical role that is not merely ancillary but instrumental to the workings of the knowledge economy'. In other words, these law firms are part of the technology community (p. 579). In terms similar to those used to describe New York's role in finance, Reiffenstein quotes Friedman et al. (1989) as saying that 'the Silicon Valley lawyer not only works with engineers, he thinks of himself as a kind of engineer - a legal engineer' (p. 578). Thus

'Silicon Valley occupies a special place in this [patent] system. Its attorneys are the "engineers" of business and legal precedent particularly as it relates to the translation of science to industry. Firms located there enjoy a locational advantage from a proximity to milieus of basic and applied research: buyers and sellers of technology' (p. 580).

This special place is a strategic place because 'every one of the major Silicon Valley law offices is a component of a much larger branch network' (p. 579) enabling the firm 'to link buyers and sellers of technology and to lubricate the innovative process by linking places' (p. 580), now necessarily including 'international transactions' (Lashinsky, 2002). Thus Palo Alto is only a small city 
but it is a big player in the strategy of law firms and therefore the world city network as our strategic-ness analyses have shown.

\section{Mexico City}

Mexico City is strongly integrated into the world city network (ranked 14th in terms of GNC) but according to our analyses it is relatively under-connected strategically (Table 4). We use Parnreiter's (2010) study of how APS firms in Mexico City operate in global commodity chains to interpret our findings in this case.

Parnreiter (2010, 36-7) begins by asking the crucial question, does the APS sector in Mexico City function as merely enabling agent of economic globalization or do these firms help shape the nature of the production networks they are servicing? To answer the question he finds he has to break with Sassen's (1991) 'equating the management of the world economy with its control' (p. 43). These are two separate mechanisms that are 'frequently conflated' despite the fact that

'it is questionable whether all high-wage, high-tech and high-profit services necessary for running global production processes are actually related to decision-making. This question is particularly relevant to global cities in non-core countries, which have a sizeable producer service sector but are normally not considered to host decision-making capacities' ( $\mathrm{p}$. 44). 
Thus although many of the practitioners he interviewed emphasize the importance of their local office within the world city network, Parnreiter is able to show that this is largely necessary work but not strategic work. He concludes 'Though at first glance it seems that the networks of producer service firms are rather flat, their organizational model implies that there is the chain of command. Despite the fact that the local cooperation is ... seen as ... essential to do business, the "big" strategies are made by the lead partners [and] the number of lead partners an office of a global service provider can have depends ... by and large on the geography of headquarters of TNCs. Since there are far fewer companies with origins in Mexico that compete successfully in the world market than foreign firms in Mexico, the Mexico City offices of accountancy, legal or real estate firms will not often be in command' (p. 47).

This is entirely consistent with our finding on the differences between Mexico City's global network connectivity and its strategic network connectivity. It also directly corresponds with the example presented above in our review of the APS literature in which the executive search firm Korn/Ferry uses a hybrid strategy to service Mexico City rather than the owned form used in the most strategic places.

Since Parnreiter frames his argument in world-systems terms, we are invited to extrapolate this interpretation to other important cities from 'non-core countries': from Table 4 and Figure 1 this would include Jakarta, Buenos Aires, Kuala Lumpur, and Mumbai. But there a complementary take is also possible: Mexico is not only non-core, it is also located in NAFTA. The fact that Toronto, 
the only Canadian city to be included in our 48 strategic places, is ranked bottom in Table 4 clearly suggests that NAFTA has tended to work for the benefit of APS firms in leading US cities at the expense of their Canadian and Mexican counterparts.

\section{Concluding remarks}

This chapter has added to our knowledge of the contemporary world city network by going beyond the basic measurement of global network connectivities to show a distinctive pattern of strategic network connectivities. Our findings appear credible and have been shown to link with literatures on selected individual cities and with work on APS and their strategic city location decisions and organizational forms. There are, of course, caveats to bear in mind when assessing these results overall.

- We have not produced definitive strategic places but rather specific strategic places relating to one economic sector, advanced producer services. We do argue the particular importance of this sector for economic globalization but there will be other strategic places for global commodity chains defined by other criteria.

- We have provided a cross-sectional analysis for 2016 to define city positionalities but, of course, these are inherently historical; information on city trajectories is a necessary addition to make better sense of our results. 
- The latter point is very relevant to the fact we have used two USA-based (with London) location strategies of firms as the basis of the analysis. This choice was justified by their being both the most important strategies identified and because they are from the world region that largely generated economic globalization. However it is their recent history and present that are being designated 'most important'; but this designation may be less relevant for the future in a dynamic world economy: Pacific Asian, especially China, location strategies will have their own emerging strategic places that our methodology is not designed to find.

What we have been able to do is provide some order in an increasingly complex economy through excavating strategic places within world city network structures. In this way we present an extensive picture in which to view the mechanisms of contemporary economic globalization.

We began with Sassen's 'global cities' as new strategic places that have solved the problem of providing operational capacity in a new global economy. Although restricting ourselves to 'spatial' identification of the strategic, this concept has still emerged as a multifarious mix of processes. In particular, our strategic places appear to have various combinations of command capacity and generation of innovations with APS firms that develop strategic presence, internationalization policies choosing to operate in these but not other cities to access such qualities. In contrast APS firms with ubiquitous strategies maintain a presence in both strategic cities and less strategic cities that act as local market nodes. 


\section{References}

Bagchi-Sen, S. and Sen, J. (1997) 'The current state of knowledge in international business in producer services', Environment and Planning A, 29, 11531174.

Beaverstock, J.V. (1996) 'Subcontracting the accountant! Professional labour markets, migration, and organisational networks in the global accountancy industry', Environment and Planning A, 28, 303-326.

Beaverstock, J.V. (2007) 'Transnational work: Global professional labour markets in professional service accounting firms,' in Bryson, J.R. and Daniels, P.W. (eds), The Handbook of Service Industries. Cheltenham, UK: Edward Elgar, 409-431.

Beyers, W. (1992) 'Producer services and metropolitan growth and development', in Mills, E.S and McDonald, J.F. (eds), Sources of Metropolitan Growth. New Brunswick, NJ: Transaction Publishers, 125146.

Bryson, J.R., Daniels, P.W. and Warf, B. (2004) Service Worlds: People, Organisations, Technologies. London: Routledge.

Coe, N.M., Johns, J. and Ward, K. (2007) 'Mapping the globalization of the temporary staffing industry', The Professional Geographer, 59, 503-520.

Cullen-Mandikos, B. and MacPherson, A. (2002) 'US foreign direct investment in the London legal market: An empirical analysis', The Professional Geographer, 54, 491-499.

Daniels, P.W. (1993) Service Industries in the World Economy. Oxford, UK: Blackwell. 
Daniels, P.W. (1995) 'The internationalisation of advertising',The Service Industries Journal, 15, 276-294.

Derudder, B., and Taylor, P.J. (2016) 'Change in the world city network, 20002012', The Professional Geographer, 68, 624-637.

Dunning, J.H. and Norman, G. (1983) 'The theory of the multinational enterprise: An application to multinational office location', Environment and Planning $A, 15,675-692$.

Enderwick, P. (1989) Multinational Service Firms. London: Routledge.

Faulconbridge, J.R. (2008) 'Managing the transnational law firm: A relational analysis of professional systems, embedded actors, and time-spacesensitive governance', Economic Geography, 84, 185-210.

Faulconbridge, J.R., Beaverstock, J.V., Nativel, C. and Taylor, P.J. (2011) The Globalization of Advertising: Agencies, Cities and Spaces of Creativity. London: Routledge.

Faulconbridge, J.R., Engelen, E., Hoyler, M. and Beaverstock, J.V. (2007) 'Analysing the changing landscape of European financial centres: The role of financial products and the case of Amsterdam', Growth and Change, 38, 279-303.

Faulconbridge, J.R., Hall, S. and Beaverstock, J.V. (2008) 'New insights into the internationalization of producer services: Organizational strategies and spatial economies for global headhunting firms', Environment and Planning A, 40, 210-234.

Grabher, G. (2001) 'Ecologies of creativity: The village, the group, and the heterarchic organisation of the British advertising industry', Environment and Planning A, 33, 351-374. 
Jones, A. (2002) "The "global city" misconceived: the myth of "global management" in transnational service firms', Geoforum, 33, 335-350.

Lai, K. (2012) 'Differentiated markets: Shanghai, Beijing and Hong Kong in China's financial centre network', Urban Studies, 49, 1275-1296.

Lashinsky, A. (2002) 'Silicon Valley: The lawyers got screwed too', Fortune, 145, 133-140.

McNeill, D. (2008) The Global Architect: Firms, Fame and Urban Form. London: Routledge.

Michie, R.C. (2006) The Global Securities Market: A History. Oxford, UK: Oxford University Press.

Parnreiter, C. (2010) 'Global cities in global commodity chains: Exploring the role of Mexico City in the geography of global economic governance', Global Networks, 10, 35-53.

Pryke, M. (1994) 'Looking back on the space of a boom: (Re)developing spatial matrices in the City of London', Environment and Planning A, 26, 235-264.

Reiffenstein, T. (2009) 'Specialization, centralization, and the distribution of patent intermediaries in the USA and Japan', Regional Studies, 43, 571588.

Sassen, S. (1991) The Global City. Princeton, NJ: Princeton University Press.

Sassen, S. (1999). 'Global financial centers', Foreign Affairs, January/February, $75-87$.

Smith, R.G. (2012) 'NY-LON', in Derudder, B., Hoyler, M., Taylor, P.J. and Witlox, F. (eds), International Handbook of Globalization and World Cities. Cheltenham, UK: Edward Elgar, 421-428. 
Strange, S. (1997) Casino Capitalism. Manchester, UK: Manchester University Press.

Taylor, M. and Asheim, B. (2001) 'The concept of the firm in economic geography', Economic Geography, 77, 315-328.

Taylor, P.J. (2001) 'Specification of the world city network', Geographical Analysis, 33, 181-194.

Taylor, P.J. and Derudder, B. (2016) World City Network: A Global Urban Analysis. 2nd edition. London: Routledge.

Taylor, P.J., Derudder, B., Hoyler, M. and Ni, P. (2013) ‘New regional geographies of the world as practised by leading advanced producer service firms in 2010', Transactions of the Institute of British Geographers, 38, 497-511.

Taylor, P.J., Hoyler, M., Pain, K. and Vinciguerra, S. (2014) 'Extensive and intensive globalizations: Explicating the low connectivity puzzle of US cities using a city-dyad analysis', Journal of Urban Affairs, 36, 876-890.

Warf, B. (2001) 'Global dimensions of US legal services', The Professional Geographer, 53, 398-406.

Wójcik, D. (2013) 'The dark side of NY-LON: Financial centres and the global financial crisis', Urban Studies, 50, 2736-2752.

Yeung, H.W.-C. (2005) 'Organizational space: A new frontier in international business strategy?' Critical Perspectives on International Business, 1, 219240. 
Table 1 Intensive and extensive globalization

\begin{tabular}{|c|c|c|c|}
\hline Intensive & Scores & Extensive & Scores \\
\hline Home-region & & Home-region & \\
\hline Washington & 7.50 & New York & 2.90 \\
\hline New York & 4.75 & London & 2.75 \\
\hline Los Angeles & 2.40 & & \\
\hline Palo Alto & 2.14 & Global outreach & \\
\hline London & 1.99 & Sao Paulo & 1.82 \\
\hline Miami & 1.25 & Mexico City & 1.55 \\
\hline Houston & 1.16 & Mumbai & 1.49 \\
\hline San Francisco & 1.01 & Istanbul & 1.47 \\
\hline Philadelphia & 0.86 & Bogota & 1.44 \\
\hline \multirow[t]{3}{*}{ Dallas } & 0.51 & Buenos Aires & 1.41 \\
\hline & & Dubai & 1.38 \\
\hline & & Milan & 1.18 \\
\hline Global outreach & & Kuala Lumpur & 1.09 \\
\hline Hong Kong & 1.60 & Johannesburg & 1.09 \\
\hline Brussels & 0.91 & Madrid & 1.09 \\
\hline \multirow[t]{28}{*}{ Beijing } & 0.54 & Santiago & 1.07 \\
\hline & & Barcelona & 1.04 \\
\hline & & New Delhi & 0.98 \\
\hline & & Moscow & 0.97 \\
\hline & & Paris & 0.96 \\
\hline & & Singapore & 0.96 \\
\hline & & Jakarta & 0.82 \\
\hline & & Lima & 0.80 \\
\hline & & Warsaw & 0.77 \\
\hline & & Caracas & 0.77 \\
\hline & & Manila & 0.77 \\
\hline & & Tokyo & 0.76 \\
\hline & & Athens & 0.73 \\
\hline & & Toronto & 0.73 \\
\hline & & Vienna & 0.66 \\
\hline & & Kiev & 0.65 \\
\hline & & Tel Aviv & 0.65 \\
\hline & & Prague & 0.63 \\
\hline & & Cairo & 0.60 \\
\hline & & Beijing & 0.59 \\
\hline & & Seoul & 0.59 \\
\hline & & Lisbon & 0.57 \\
\hline & & Bangkok & 0.56 \\
\hline & & Hong Kong & 0.56 \\
\hline & & Montevideo & 0.55 \\
\hline & & Bucharest & 0.53 \\
\hline & & Beirut & 0.53 \\
\hline & & Sofia & 0.50 \\
\hline
\end{tabular}


Table 2 Global strategic firms

\begin{tabular}{lcll}
\hline APS firms & $\begin{array}{c}\text { Global strategic } \\
\text { measure }\end{array}$ & Sector & Headquarters \\
Cleary Gottlieb & 0.182 & Law & New York \\
Sullivan \& Cromwell & 0.158 & Law & New York \\
White \& Case & 0.157 & Law & New York \\
Citi & 0.153 & Finance & New York \\
Ogilvy \& Mather & 0.144 & Advertising & New York \\
Simpson Thacher \& Bartlett & 0.125 & Law & New York \\
Clifford Chance & 0.120 & Law & London \\
Baker \& McKenzie & 0.114 & Law & Chicago \\
Skadden, Arps, Slate, Meagher \& Flom & 0.111 & Law & New York \\
BKR International & 0.110 & Accountancy & New York \\
Mayer Brown & 0.110 & Law & Chicago \\
Morgan Stanley & 0.108 & Finance & New York \\
Goldman Sachs & 0.104 & Finance & New York \\
Publicis Healthcare Communications & 0.099 & Advertising & New York \\
Group & 0.095 & Finance & Brasilia \\
Banco do Brasil & 0.088 & Law & London \\
Allen \& Overy & 0.086 & Finance & London \\
HSBC & 0.084 & Finance & Tokyo \\
Nomura & 0.084 & Law & London \\
Linklaters & 0.083 & Accountancy & London \\
Moore Stephens International & 0.083 & Management & New York \\
Alvarez \& Marsal & 0.082 & Finance & Sao Paulo \\
Bradesco & 0.082 & Finance & New York \\
J.P. Morgan & 0.082 & Law & Washington \\
Jones Day & 0.082 & Law & Los Angeles \\
Latham \& Watkins & & & \\
\hline
\end{tabular}


Table 3: Strategic network connectivity

\begin{tabular}{|c|c|c|c|}
\hline Rank & city & Strategic network Connectivity & Number of offices \\
\hline 1 & New York & 7124 & 25 \\
\hline 2 & London & 6833 & 25 \\
\hline 3 & Hong Kong & 5375 & 24 \\
\hline 4 & Washington & 4383 & 23 \\
\hline 5 & Paris & 4162 & 23 \\
\hline 6 & Dubai & 4025 & 19 \\
\hline 7 & Frankfurt & 3811 & 21 \\
\hline 8 & Tokyo & 3799 & 22 \\
\hline 9 & Singapore & 3763 & 18 \\
\hline 10 & Sao Paulo & 3614 & 22 \\
\hline 11 & Beijing & 3583 & 22 \\
\hline 12 & Chicago & 3580 & 16 \\
\hline 13 & Moscow & 3393 & 18 \\
\hline 14 & Milan & 3337 & 20 \\
\hline 15 & Brussels & 3334 & 18 \\
\hline 16 & Amsterdam & 3243 & 16 \\
\hline 17 & Los Angeles & 3223 & 17 \\
\hline 18 & Shanghai & 3215 & 21 \\
\hline 19 & Madrid & 3196 & 19 \\
\hline 20 & Sydney & 3098 & 17 \\
\hline 21 & Mexico City & 2873 & 14 \\
\hline 22 & Seoul & 2682 & 19 \\
\hline 23 & Warsaw & 2618 & 14 \\
\hline 24 & Istanbul & 2597 & 13 \\
\hline 25 & Miami & 2597 & 12 \\
\hline 26 & San Francisco & 2552 & 14 \\
\hline 27 & Stockholm & 2298 & 13 \\
\hline 28 & Luxembourg & 2280 & 12 \\
\hline 29 & Taipei & 2271 & 11 \\
\hline 30 & Jakarta & 2228 & 14 \\
\hline 31 & Bangkok & 2191 & 13 \\
\hline 32 & Mumbai & 2164 & 10 \\
\hline 33 & Johannesburg & 2137 & 12 \\
\hline 34 & Zurich & 2123 & 11 \\
\hline 35 & Buenos Aires & 2058 & 12 \\
\hline 36 & Munich & 2043 & 12 \\
\hline 37 & Hanoi & 2006 & 12 \\
\hline 38 & Riyadh & 2003 & 14 \\
\hline 39 & Melbourne & 1983 & 10 \\
\hline 40 & Doha & 1982 & 11 \\
\hline 41 & Toronto & 1938 & 11 \\
\hline 42 & Houston & 1930 & 13 \\
\hline 43 & Abu Dhabi & 1902 & 11 \\
\hline 44 & Boston & 1873 & 11 \\
\hline 45 & Rome & 1862 & 12 \\
\hline 46 & Düsseldorf & 1737 & 11 \\
\hline 47 & Ho Chi Minh City & 1733 & 10 \\
\hline 48 & Palo Alto & 1560 & 10 \\
\hline 49 & Barcelona & 1524 & 10 \\
\hline
\end{tabular}


Table 4 Residual from regressing strategic network connectivity against global network connectivity

\begin{tabular}{|c|c|c|}
\hline Rank & city & Residual \\
\hline 1 & Washington & 3.054 \\
\hline 2 & Palo Alto & 2.156 \\
\hline 3 & New York & 2.087 \\
\hline 4 & Hong Kong & 1.676 \\
\hline 5 & Frankfurt & 1.123 \\
\hline 6 & London & 1.084 \\
\hline 7 & Brussels & 1.005 \\
\hline 8 & Los Angeles & 0.847 \\
\hline 9 & Hanoi & 0.815 \\
\hline 10 & Amsterdam & 0.703 \\
\hline 11 & Miami & 0.555 \\
\hline 12 & Doha & 0.538 \\
\hline 13 & Abu Dhabi & 0.491 \\
\hline 14 & Chicago & 0.470 \\
\hline 15 & Madrid & 0.408 \\
\hline 16 & San Francisco & 0.349 \\
\hline 17 & Houston & 0.346 \\
\hline 18 & Dubai & 0.304 \\
\hline 19 & Moscow & 0.282 \\
\hline 20 & Sao Paulo & 0.280 \\
\hline 21 & Luxembourg & 0.097 \\
\hline 22 & Munich & 0.059 \\
\hline 23 & Paris & 0.005 \\
\hline 24 & Rome & -0.001 \\
\hline 25 & Stockholm & -0.165 \\
\hline 26 & Milan & -0.176 \\
\hline 27 & Seoul & -0.328 \\
\hline 28 & Boston & -0.329 \\
\hline 29 & Taipei & -0.342 \\
\hline 30 & Riyadh & -0.371 \\
\hline 31 & Tokyo & -0.406 \\
\hline 32 & Düsseldorf & -0.492 \\
\hline 33 & Istanbul & -0.502 \\
\hline 34 & Bangkok & -0.516 \\
\hline 35 & Ho Chi Minh City & -0.580 \\
\hline 36 & Warsaw & -0.607 \\
\hline 37 & Zurich & -0.609 \\
\hline 38 & Buenos Aires & -0.668 \\
\hline 39 & Mexico City & -0.670 \\
\hline 40 & Sydney & -0.727 \\
\hline 41 & Beijing & -0.818 \\
\hline 42 & Jakarta & -1.030 \\
\hline 43 & Melbourne & -1.085 \\
\hline 44 & Barcelona & -1.105 \\
\hline 45 & Shanghai & -1.145 \\
\hline 46 & Singapore & -1.194 \\
\hline 47 & Johannesburg & -1.396 \\
\hline 48 & Toronto & -1.647 \\
\hline
\end{tabular}


